\title{
Digital Humanities in the Conservation of Cultural Heritage
}

\author{
Marina A. Lapteva*, Eugenia A. Gordeeva ${ }^{a}$ \\ and Alexei A. Laptev ${ }^{\text {b* }}$ \\ a Siberian Federal University \\ 79 Svobodny, Krasnoyarsk, 660041, Russia \\ ${ }^{b}$ University of Information Technologies, Mechanics and Optics \\ 49 Kronversky av., St. Petersburg, 197101, Russia
}

Received 19.02.2016, received in revised form 24.04.2016, accepted 09.05.2016

The use of digital technologies in science has contributed greatly to the creation of new scientific directions and research aspects. The paper discusses tools, aims, methods and administrative instruments used in Digital Humanities for national and international projects. The authors also consider the projects of building DH centers and applying digital tools to research in philosophy, education, history, linguistics, and musical studies. The authors discuss the impact of DH in cultural heritage using several national and international projects as case studies.

Keywords: visual culture, humanities, digital culture, digital era, digital humanities, human sciences, digital technology, computer science, humanities computing.

DOI: 10.17516/1997-1370-2016-9-7-1682-1689.

Research area: culture studies.

\section{Introduction}

The digital technology used in the field of humanities has been firmly established as a very effective in application methodological tool. Large-scale changes in the approaches to the general digitalization of the surrounding area, as a rule, contribute to the creation of new trends and research directions. A number of interesting research projects with the use of digital technologies are implemented in an interdisciplinary field, involving researchers from various knowledge fields: linguistics, history, sociology, cultural history, etc. As a result, there is a tendency of so-called "digital revolution", which set a new field of research Digital Humanities [Volodin, 2014].

\section{Digital Humanities as a scientific discipline}

What are Digital Humanities: science, methodology, or technology? There are different opinions on this matter. Digital Humanities (hereinafter referred to as $\mathrm{DH}$ ) can be regarded as computer science with a humanitarian orientation, which formed either a scientific field or an academic discipline. During her stay in

(c) Siberian Federal University. All rights reserved

* Corresponding author E-mail address: krasmargo@mail.ru; alaptev91@yandex.ru 
Krasnoyarsk, Melissa Terras in the lecture for students of the School for Humanities expressed her own opinion: "Although the study of university curriculum cannot give an unambiguous answer to the question about the extent of the value of this discipline, this study answers the important questions that arise in the process of formation of university curriculum and practical application of programs in educational activity. In the end, there appears an understanding of the ideology of the discipline". Perhaps, humanities computing in general is not a separate discipline? And can it exist as a definite subject?

Certainly, interest in the Digital Humanities is growing, new tools are formed, and used methods acquire clear characteristics, so the object of research becomes clear. The use of information technology is widespread in many spheres of human activity. "Today it is difficult to hold a disciplinary demarcation, to establish where the borders between sciences are, though the sciences persistently fought for their autonomy over the past few centuries" [Kuz'mina, Prudenko, 2012]. Attempts to identify the basic principles and the limits of research in the field of Digital Humanities were taken within two manifestos: The Digital Humanities Manifesto 2.0 in June 2009 [www.humanitiesblast.com/manifesto/ Manifesto_V2.pdf] and the Manifesto for Digital Humanities (Paris, 2010). Interdisciplinary nature of Digital Humanities, according to manifestos' authors, is nothing more or less than a result of hybrid forms of communication, which are the hallmark of modern culture.

Over many years of development and formation of DH as a scientific discipline, there has been a significant increase in understanding of the research areas and the increment of knowledge about the coexistence of human and digital worlds. Furthermore, this science has not only declared, but also firmly established itself, has found its niche and approach to the implementation of humanitarian research projects in the digital age.

\section{Areas of research in the digital humanities}

As regards the role of the Digital Humanities in conservation of cultural heritage, in the first place, it is worth acknowledging achievements of Western colleagues. To date, they may submit a portfolio of dozens of catalogs with hundreds of projects. After an empirical analysis of the contents of the above mentioned catalogues, one can easily come to the conclusion that the project activity in the Digital Humanities in the west is evenly distributed among such sciences as anthropology, archeology, art, literature, geography, history, literature, linguistics, philosophy and religion.

One project, called The Digital Scriptorium, includes a constantly updated digital database of text images of medieval and Renaissance manuscripts [http://vm136.lib.berkeley.edu/ BANC/digitalscriptorium/]. It is noteworthy that the images have the highest quality, are freely available and optimized for viewing on mobile and ordinary platforms. Thus, developed at the University of California, Berkeley, this digital database brings together the resources of many educational institutions in the international tool for teaching and research. It means that The Digital Scriptorium facilitates filling up the limited resource of local libraries by providing enthusiastic users with a unique opportunity not just to explore the text, reprinted from the manuscript, but to get acquainted with the original text and all its specific calligraphic zest.

Another interesting project is the The Antiquity A-la-carte, the University of North Carolina. The Antiquity A-la-carte is the application on the basis of geographic information system (GIS ), i.e. a digital atlas of the ancient world, showing the exact historical, cultural and geographical data. This map is fully interactive 
and has a wide range of configurable features, filters and tools of user search for items within the framework of some scientific work or studying the particular event [http://awmc.unc.edu/awmc/ applications/alacarte/].

An outstanding project was initiated by Stephen Murray, Professor of Art History and Archaeology, Columbia University. Using visual resources at the Vassar College Library, he has created the project The Mapping Gothic France [http://mappinggothic.org/]. The project is to provide the researcher of Gothic architecture in France with somewhat different from the usual graphic form. The created web-gallery in addition to the images of gothic architecture in France includes an accompanying audio narrative that helps the user to establish a link between the architectural space of the individual buildings, geopolitical space and the result of this interaction (collaboration and conflict between the builder and the customer).

Scientists at Cambridge University have created another remarkable project, called Online Calendar of the Correspondence of Charles Darwin [http://www.darwinproject.ac.uk/]. The project in this case is an interactive virtual mail box of Charles Darwin containing a majority of sent and received letters, the number of which exceeds 15,000 . Interestingly, the restoration of the text of the work is still under way and the projected date of work completion is 2022. In addition to the interactive mailbox, the resource page displays detailed graphs and charts that divide the correspondence of Charles Darwin according to various parameters concerning the user interests. The resource is the standard reference work for scholars.

\section{Global alliances and associations of digital research}

There are several associations that successfully implement a number of projects at a global level. These associations are endowed with functions that are able not only to promote and support new interdisciplinary direction, but also to initiate new research topics, particularly addressing the task of preserving and updating the cultural space. The Alliance of Digital Humanities Organizations (ADHO) has recently been considered the most popular association in this field. It is an association that supports digital research and development in all fields of arts and humanities, acting as a consultant. The aim of the alliance is to unite specialists from the two areas: humanities and IT. ADHO covers and coordinates the work with digital technology around the world by combining the largest associations [Alliance of Digital....].

The European Association for Digital Humanities (EADH) is the founder and the head of the international organization The Alliance of Digital Humanities Organizations $(A D H O)$. EADH consolidates and represents the latest technology in Europe, across the entire spectrum of disciplines, research, development and application of digital techniques in the humanities. Central area of of the association research is the analysis of texts and languages. EADH maintains creation of groups of humanities computing in Europe, which are formed according to regional, linguistic, methodological and other criteria.

Since the range of available and appropriate computational methods in the humanities extends significantly, the interests of association members progress too, and today they include not only the analysis of the text and language, but also history, art history, music history, manuscript studies, image processing and electronic publications. The new name of the association, which was adopted in 2012, reflects the momentous expansion of business. Today EADH mission is representation of the European digital humanities research in all disciplines. 
There are other associations, which join in the World Alliance (ADHO). Association "Computer and Humanities" (ACH) is one of the major professional communities for digital humanities. Association supports and disseminates research in these areas, as well as contributes to the formation of a new professional community through conferences, publications and organization of awareness-raising activities. $\mathrm{ACH}$ is based in the US, but also includes representatives in other countries.

CenterNet is an international network of digital humanities centers formed together for the sake of digital humanities fields and related areas in general, as well as for the sake of the centers of humanities cyber infrastructure. CenterNet helps separate DH-centers to exchange experience, to create instruments of research and to contribute to the appearance of international research teams. Through such projects as Day (s) of DH and Resources for Starting and Sustaining DH Centers, CenterNet builds a virtual DH-center, namely, a platform for digital humanities to be studied by broad scientific community.

Australian Association of Digital Humanities Research (aaDH) was founded in March 2011 to strengthen the digital research of the humanities community in Australia and New Zealand. Canadian community of digital humanities research (Canadian Society for Digital Humanities) has been an association of representatives of a majority of Canadian colleges and universities since 1986. The Society was founded as a consortium of humanities computing. The main goal was to bring together the specialists in humanities, who were engaged in digital and computer research and development of new data processing techniques. With such a rapid development of the digital humanities field humanities undergo a radical transformation. In response to this situation, striving to combine humanities and information technology researchers in Japan made efforts to establish professional unions. For example, there was limited cooperation between Japanese experts in the field of digital humanities research and their counterparts in the West, due to difficulties with the digitization of images and texts, kept in Japanese resources. To resolve these issues and problems, the Japanese Association of Digital Humanities Research (JADH) was created. Its purpose was the organization of such environment in which international collaborations will be performed in full.

Review of the activities of these associations reveals a wide range of human studies using digital technology and giving visible results immediately. There are scientific links between them; there are many joint projects; every year conferences, forums and seminars are held in different cities around the world.

\section{Russian experience in the application of digital technologies for conservation of cultural heritage}

In Russia, the situation is somewhat different. At this stage of Digital Humanities development, the digital technologies have not sufficiently spread in the social and cultural environment in the country yet. However, there are some projects, which undoubtedly deserve attention. A number of cities have their own laboratories and departments (Moscow, St. Petersburg, Yekaterinburg, Barnaul, Tobolsk, Tomsk, Krasnoyarsk). Despite the fact that these are, for the most part, only university structures, the prospects of their development and transformation into the research centers are quite vivid. Then, in turn, the research centers would be able to develop and provide new methods and technologies for conservation of cultural and historical heritage.

In 2014 in Tomsk at the Department of Humanities Informatics Problems of Tomsk State University the project "Humanities in the 
Digital Age: from Sectoral Informatics to Digital Humanities" was launched. The project aims to study current trends in the humanities who actively use the potential of information technologies for research tasks whose solution is of fundamental importance for determination of the potential scope and impact of digital technologies. The project uses modern digital technologies that are fundamentally changing the scope, purpose and effects of Digital Humanities. Project activities are positioned as collective and interdisciplinary, which helps eliminate the boundaries between the two leading areas: humanities and IT.

We reached a new level in Internet research. The eponymous project Internet Studies $\mid$ Internet Research in Russia is successfully implemented on the basis of the Institute of Fundamental and Applied Studies of Moscow University for the Humanities, and University College in London. The project's main purpose is the exchange of experience in the already realized projects and dissemination of practices of the Internet study among the Russian scientists.

One of the most important projects in this sphere is "Returned Names" launched by National Library of Russia in St. Petersburg and aimed at creating an electronic database of victims of political repression in the Soviet Union [ http://visz.nlr.ru/project/reg/peter.html], In May 2000, representatives of government and civil organizations in Russia and CIS held a joint conference, where they stated the importance and significance of the "memorial" project. Coordination centers of the project appeared in Nizhny Tagil, Krasnoyarsk, Almaty, Odessa, Moscow and St. Petersburg.

In Moscow State University named after M.V. Lomonosov at Faculty of History there is the Department of Historical Informatics. Particularly noteworthy are their projects focused on the virtual reconstruction of objects of cultural and historical heritage, monasteries of Moscow in particular. Within the project not only the monasteries were restored, but also the researchers analyzed the evolution of the spatial infrastructure, using 3D-modeling techniques. We should admit, however, polydisciplinary character of membership in such projects. The members include historians, restorers, architects, art historians and IT-specialists.

Currently Russia has more than 20 centers of historical informatics. All of them are members of the "History and Computer" Association, and since 1993 they have been organizing seminars and conferences. These meetings allow scientists to assess the priorities of various scientific fields in Digital Humanities and to determine further prospects.

One such workshops of "History and Computer" Association was held in Krasnoyarsk in 2011 at the Department of Information Technologies in the Creative and Cultural Industries of Siberian Federal University (School for the Humanities). As the result there was released Collection of Proceedings "Virtual reconstruction of historical and cultural heritage in forms of scientific research and educational process" [Borodkin, 2012]. The workshop identified another area of Digital Humanities, requiring special attention, which is conservation of cultural and historical monuments which are in danger of collapsing due to the lack of funding, needed for the object timely restoration.

For the past six years, the Department of Information Technologies in the Creative and Cultural Industries has participated in the development technology, capable of visualizing museum collections. With various Russian museums Department has carried out cooperation in formulating and solving specific problems. The beginning of the joint work of the University and the State Russian Museum could be considered a very successful work in the digitalization of museum collections, which resulted in the digital 
form of famous paintings of great Russian artists. The specialists used a robotic tripod by GigaPan, which allows making digitization of artifacts in high-resolution with multiple zooming. Among these paintings were works by Vasily Surikov - "Capture of the Snow Town", "Conquest of Siberia by Yermak", Ivan Shishkin - "The Ship Grove", Ivan Aivazovsky - "The Ninth Wave" and others. This technology enables users to explore the picture in more detail, which may be impossible in reality in the museum.

Simultaneously, Department is engaged in shooting spherical panoramas. So, the result of the collaboration with the Russian Museum was more than 200 spherical panoramas of interiors and exteriors of the main buildings and landscapes, which were later used to create virtual tours.

During the last three years the Laboratory of Humanitarian Informatics of Siberian Federal University has been working with the State Hermitage Museum, which offers more and more new ideas for the university students' work. The important point was the use of augmented reality technology, applied in the Restoration and Storage Centre "Old Village “. Threedimensional visualization of archaeological sites allows viewers to see copies of the unique ancient artifacts in the adequate context.

Panorama shooting of the historically significant for St. Petersburg space opens up new possibilities for each person whose need is contemplation of beauty and search for values in the usual things. After all, in the museum environment there are a lot of non-public places. Spherical panoramas give the visitor a chance to see them [Pikov, Lapteva, 2015].

In September 2015, Siberian Federal University hosted first in Siberia international scientific-practical conference "Information Technologies in the Humanities". The organizer of this event was School for the Humanities of the University. During the conference, the researchers stated and discussed main topics related to the development of Digital Humanities. The participants of the conference were not only Russian scientists from Moscow, St. Petersburg, Barnaul, Tomsk, Krasnoyarsk and Novosibirsk, but also well-known in the field foreign researchers from the Netherlands, the UK, Switzerland, the USA. The key issue of the conference was discussing the possibility of using modern digital technologies in humanities research. The conference was focused on solving the problems connected with electronic data, computer linguistics, digital art in all its forms and new possibilities of computer modeling of historical events. The particularly important discussion was one devoted to the themes of the allocation of resources in the humanities, interdisciplinary character of the new direction as educational bases in the structures of the federal education and the use of interactive multimedia technologies in culture and art. During the conference the specialists became aware of the described above work of the European Association of Digital Humanities. Claire Clive, Head of the Department of Information Technology in Education of the Swiss Institute of Bioinformatics, told in her presentation about the opportunities and the basic principles of publishing the project results on the Internet.

Presentations by leading scientists in the field of digital humanities concerned modeling issues in the humanities and its connection with the history of engineering and technological Sciences, presented the approaches to the analysis of a variety of methods of publications in digital humanities, GIS (geographic information systems) in the humanities, cross-domain data in digital humanities. Presented at the sections projects have opened up new opportunities for cooperation and new areas of research. By their nature, they are all aimed at conservation and representation of cultural and historical heritage. 


\section{Conclusion}

Nowadays we are witnessing the formation of a new culture that has been influenced by digital technology. The new culture is a complex phenomenon, the fusion of a plurality of areas. In this culture the rightful place should be given to heritage of the past. This is not simple, and it is impossible to do this without the use of new digital technologies, which enable not only visualization of the object, but also its correct interpretation. These new technologies make it possible to perceive the past in the contexts, relevant and adequate in relation to the present, while maintaining the integrity and "correctness" of perception.

\section{References}

Alliance of Digital Humanities Organizations. Available at: http://adho.org.

Borodkin, L. I. (2014). Virtual'naia rekonstruktsiia monastyrskikh kompleksov Moskvy: proekty v kontekste Digital Humanities [Virtual reconstruction of the monasteries of Moscow: projects in the context of the Digital Humanities], In Vestnik Permskogo universiteta. Seriia: Istoriia [Perm University Herald. Series “History”], 3 (26), 107-112.

Borodkin, L. I., Rumiantsev, M. V., Baryshev, R. A. (2012). Virtual'naia rekonstruktsiia istorikokul'turnogo naslediia $v$ formatakh nauchnogo issledovaniia i obrazovatel'nogo protsessa [Virtual reconstruction of historical and cultural heritage in the forms of scientific research and educational process]. Krasnoyarsk, Siberian Federal University, 196 p.

Garskova, I.M. (2014). Informatsionnoe obespechenie gumanitarnykh issledovanii $\mathrm{v}$ tsifrovuiu epokhu: modeli formirovaniia i razvitiia [Information support of human studies in the digital era: a model of formation and development], In Vestnik Permskogo universiteta. Seriia: Istoriia [Perm University Herald. Series "History"], 3 (26), 20-28.

Gorbunova, I.B. (2015). Muzykal'no-komp'iuternye tekhnologii v perspektive Digital Humanities[Music and computer technology in the future Digital Humanities], In Obshchestvo: filosofiia, istoriia, kul'tura [Society: philosophy, history, culture], 3, 5.

Kizhner, I. et al. Digital Humanities at Siberian Federal University. Available at: http://www. digitalstudies.org/ojs/index.php/digital_studies/article/view/288/354

Kuz'mina, D.Iu., Prudenko, Ia.D. (2012). Gumanitarnye nauki v tsifrovoi vek [Humanities in the digital age], In Mezhdunarodnyi zhurnal issledovanii kul'tury [International Journal of Cultural Studies], 3, 7.

Online calendar of the correspondence of Charles Darwin. Available at: http://www.darwinproject.ac.uk/.

Pikov, N.O., Lapteva, M.A. (2015). Tekhnologii vizualizatsii v muzee (Iz opyta sotrudnichestva SFU s muzeiami Rossii) [Visualization Technology in the museum (from the experience of SFU's cooperation with Russian museums)], In Sbornik tezisov dokladov mezhdunarodnoi nauchnoprakticheskoi konferentsii "Informatsionnye tekhnologii v gumanitarnykh naukakh [Abstracts of the International Scientific and Practical Conference "Information Technologies in the Humanities"]. Krasnoyarsk, Siberian Federal University, 28-29.

Serbin, V.A., Mozhaeva-Ren'ya, P. N., Mozhaeva, G.V. (2014). Tsifrovaia gumanitaristika: organizatsionnye formy i infrastruktura issledovanii [Digital humanities: organizational forms and research infrastructure], In Vestnik Tomskogo gosudarstvennogo universiteta [Tomsk State University Journal], 389, 73-81. 
The Antiquity À-la-carte. Available at: http://awmc.unc.edu/awmc/applications/alacarte/

The Digital Humanities Manifesto 2.0. Available at:www.humanitiesblast.com/manifesto/ Manifesto_V2.pdf

The Digital Scriptorium. Available at: http://vm136.lib.berkeley.edu/BANC/digitalscriptorium/

The Mapping Gothic France. Available at: http://mappinggothic.org/

Vanhoutt, E., Nyhan, J., Terras, M. (eds). (2013). Defining digital humanities: a reader. Ashgate Publishing, Ltd., 256 p.

Volodin, A. Iu. (2014). Digital Humanities (tsifrovye gumanitarnye nauki): v poiskakh samoopredeleniia [Digital Humanities (humanities computing): Searching for self-definition], In Vestnik Permskogo universiteta. Seriia: Istoriia [Perm University Herald. Series "History”], 3 (26), $5-12$.

Vozvrashchennye imena: Sankt-Peterburg [Returned Names: Saint-Petersburg]. Available at: http://visz.nlr.ru/project/reg/peter.html.

\title{
Digitalhumanities в деле сохранения
}

\section{культурного наследия}

\author{
М.А. Лаптева ${ }^{a}$, Е.А. Гордеева ${ }^{a}$, А.А.Лаптев ${ }^{\sigma}$ \\ ${ }^{a}$ Сибирский федеральный университет \\ Россия, 660041, Красноярск, пр. Свободный, 79 \\ ${ }^{6}$ Санкт-Петербургский национальный \\ исследовательский университет \\ информационных технологий, механики и оптики \\ Россия, 197101, Санкт-Петербург, Кронверкский проспект, 49
}

\begin{abstract}
Использование цифровых технологий в научных исследованиях поспособствовало формированию новых научных направления и исследований. Статья посвящена вопросам использования технологий циифровых гуманитарных наук и организационного оформления DHпроектов в мировом и отечественном профессиональном сообществе. Авторы раскрывают задачи, формы и виды деятельности общества в области Digital Hитапіties. Особое внимание обращается на практическую базу проектов по функиионированию организаций подобного профиля. Также рассматривается проблема применения информационных технологий в такихгуманитарных науках, как философия, педагогика, история, лингвистика имузыкальное искусство. На основе анализа мировых и отечественных проектов, результативности их практической деятель-ности, а также характера взаимодействия между организациями определяется степень участия Digital Huтаnities и перспективы развития в деле сохранения культурного наследия.
\end{abstract}

Ключевые слова: визуальная культура, гуманитарные науки, иифровая культура, цифровая эпоха, цифровые гуманитарные науки, гуманитарная информатика, иифровые технологии.

Научная специальность: 24.00.00 - культурология. 